\title{
Comparison of barriers faced by women in the Australian and Indian construction industry.
}

\section{Comparación de las barreras que enfrentan las mujeres en la industria de la construcción de Australia e India.}

\author{
Priya Paul \\ Science Engineering and Built Environment Deakin University Geelong, Australia
}

Correponding Author mail id:paul.priya@outlook.com.au

\begin{abstract}
Today's construction industry has extreme gender stratification that is still traditional in the employment of women. Even though the participation of women in the construction industry has grown, women are still considered as a minority in this field. The industry is considered as male-dominated with low participation of women. The aim of this study is to compare the challenges faced by women construction workers in two different countries: Australia and India. In this context, the study also investigated the level of participation of women in the construction industry and the common challenges faced by women that hinder their participation around the globe. The significant barriers that are faced by women construction workers around the globe are the male-dominated nature and masculine culture of the industry, work-family balance, lack of career progression, longer working hours and the complex workplace culture. When comparing the barriers faced by women in the Indian and Australian construction industry, some of them similar, whereas some are different. The barriers faced by women in Australia are gender stereotyping, lack of awareness, the rigidity of work roles, flexibility issues and changing the family structure. On the other hand, In India, women face barriers such as unequal wages, caste, cultural and religion restrictions, poor sanitary facilities, seasonal work irregularity and health hazards. The research proves that there are many barriers that counteract the participation of women in the industry and thus recommends some measures to improve their involvement.
\end{abstract}

Keywords: Women, Construction industry, Challenges or barriers or problems, Indian and Australian construction industry, Gender discrimination.

\section{RESUMEN}

La industria de la construcción actual tiene una estratificación de género extrema que todavía es tradicional en el empleo de mujeres. Si bien ha aumentado la participación 
de las mujeres en la industria de la construcción, todavía se considera a las mujeres como una minoría en este campo. Se considera que la industria está dominada por hombres con una baja participación de mujeres. El objetivo de este estudio es comparar los desafíos que enfrentan las trabajadoras de la construcción en dos países diferentes: Australia e India. En este contexto, el estudio también investigó el nivel de participación de las mujeres en la industria de la construcción y los desafíos comunes que enfrentan las mujeres que dificultan su participación en todo el mundo. Las barreras importantes que enfrentan las trabajadoras de la construcción en todo el mundo son la naturaleza dominada por los hombres y la cultura masculina de la industria, el equilibrio entre el trabajo y la familia, la falta de progresión profesional, las horas de trabajo más largas y la compleja cultura del lugar de trabajo. Al comparar las barreras que enfrentan las mujeres en la industria de la construcción de India y Australia, algunas son similares, mientras que otras son diferentes. Las barreras que enfrentan las mujeres en Australia son los estereotipos de género, la falta de conciencia, la rigidez de los roles laborales, los problemas de flexibilidad y el cambio de la estructura familiar. Por otro lado, en India, las mujeres enfrentan barreras como salarios desiguales, restricciones de casta, culturales y religiosas, instalaciones sanitarias deficientes, irregularidad en el trabajo estacional y riesgos para la salud. La investigación demuestra que existen muchas barreras que contrarrestan la participación de las mujeres en la industria y por ello recomienda algunas medidas para mejorar su implicación.

Palabras clave: mujeres, industria de la construcción, desafíos o barreras o problemas, industria de la construcción de India y Australia, discriminación de género

\section{INTRODUCTION}

Civil engineering has 'building' as its background and major the works include town planning, structural engineering, basic designing, surveying, and constructing. Construction industry serves as the backbone of the major economies of the world. It is a wide industry utilizes around 1.77 million individuals, of which under $10 \%$ are women [Balancing the BuildingTeam;1995]. Thus, the construction sector is truly depicted as a non-conventional occupation for women. The absence of gender diversity in the development segment is a tenacious issue perceived everywhere throughout the world, which increases skills shortages, diminishes efficiency and advancement [T. Toohey et.al;2021].

Today's construction industry has extreme gender stratification that is still traditional in the employment of women [Linda Clarke et.al;2015]. Even though the participation of women in the construction industry has grown, women are still considered as a minority in this field [J. Swanson et.al;1996]. There are many problems that are faced by women in the construction industry. This research study mainly investigates the challenges and barriers that hinder the involvement of women in the construction industry 
and then compare them between Indian and Australian construction industry.

The chief purpose of the study is to compare the reasons and challenges that hinder the involvement ofwomen in the construction industry, specifically in two countries: India and Australia.

The objectives for the above-listed aims are the following:

- To explore the status of women in the construction industry and to recapitulate prevailing studies and literature.

- To find various career barriers and challenges faced by women in the construction industry.

- To provide recommendations and moral practices to encourage employment, retention, and development of women in construction.

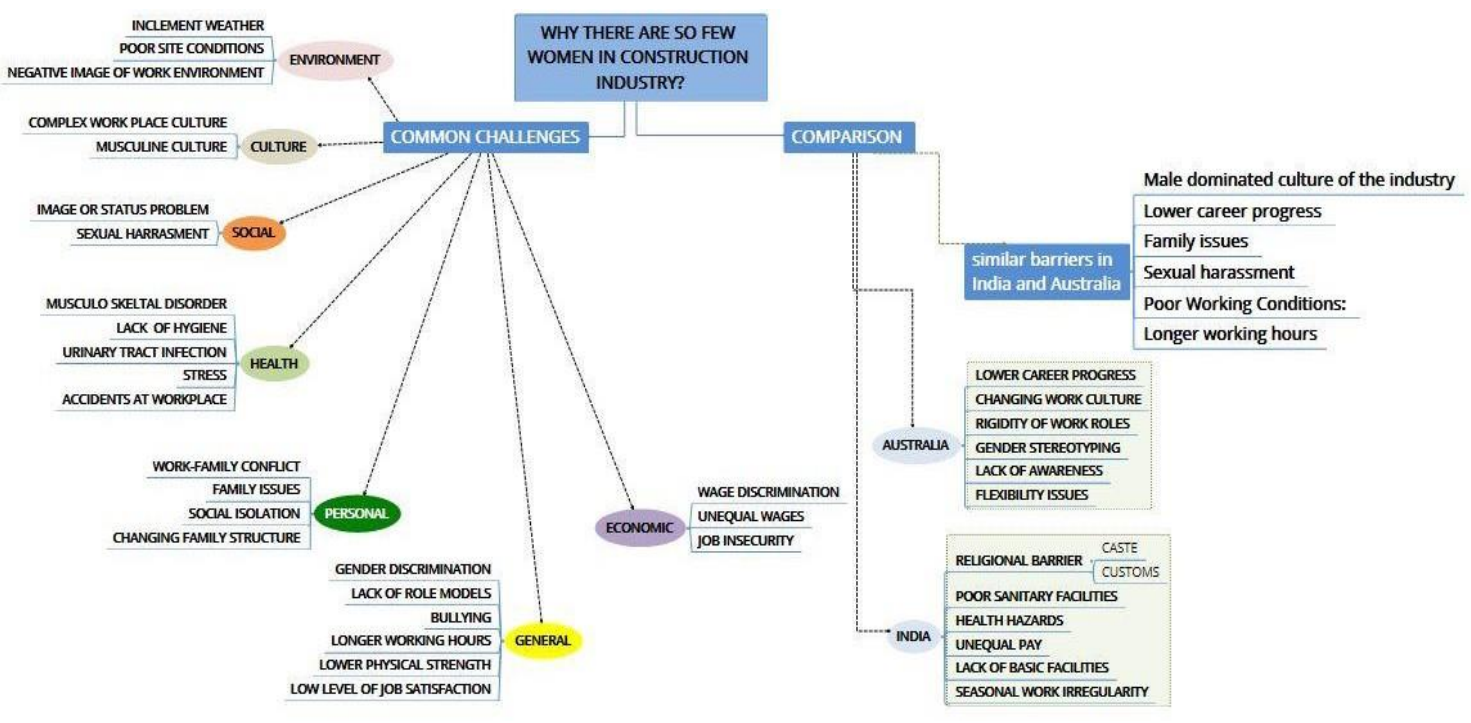

Fig. 1 Developed concept map for the proposed research

Fig. 1 is a developed concept map that provides an overall idea of this research

MATERIALS AND METHODS

In this specific research contemplate, a qualitative analysis method was used to accomplish the objectives of the study. Within the qualitative method, the process involves systematic literature review method. The investigation of various literature will provide surplus information for the comparison of the barriers that confront the participation of women in the Australian and Indian construction industry. To analyse the common career barriers faced by women in the construction industry around the globe, the framework analysis method is used. This framework is used to categorise the barriers into different groups.

Data collection: Due to the limitation of time and access to the location, the data used for this research is the secondary data which is gathered from reviewing documents and literature. Secondary research includes the summary, assembling or synthesis of 
existing study. The documents for the research were collected from different articles, academic journals, government reports and newspaper. Following steps were followed to collect data for this research:

Stage 1: Investigation of research resources using keywords such as women in construction, barriers or challenges, Indian and Australian construction industry, Participation of women in construction, and gender discrimination.

Stage 2: Reviewing the abstract, introduction, and conclusion to filter the most suitable material.Stage 3: Research examination to recover critical data for a further research study

Status of women in the construction industry: Today's construction industry is conservative in engaging women due to extraordinary gender discrimination. The Women's Bureau of the Department of Labour portrays construction industry as a non-traditional or male overpowered industry which contains $25 \%$ or fewer women involvement Earnings and Earnings ratio;2021]. Although construction is a good choice of profession for women, there is so far a mind-blowing gap among their participation when compared to men. Women generally face different encounters as they advance in their profession, and this is most common in the construction industry [N. Galea et.al;2015]. A few numbers of women are choosing the construction profession because of several factors that influence their careerdecision [T. Toohey et.al; 2021]. Most women in developed countries are employed as managers and administrators. According to studies, the engagement of women at the skilled engineering level is fewer and they represent less than $1 \%$ of the entire workforce in different countries [Linda Clarke et.al;2020]. In developing nations, women represent just a small proportion of all workers in the construction industry. Women are commonly employed as workers or labourers at construction and building material sites in these countries. Womenare put underneath in the job hierarchy, as untalented labourers, and head-stack transporters. They additionally do probably the hardest and most troublesome undertakings and are paid not as much as men doing comparative tasks.

\section{RESULTS AND DISCUSSION}

There are several barriers restricting the participation of women in construction. The results from the data analysis highlight the substantial barriers that hinder the participation of women in the construction industry. The significant barriers that hinder women into the industry are as follows: - Male dominated the industry - The masculine and complex workplace culture of the industry [A. Dainty and H. Lingard;2006] - Workfamily conflict [ R. Wentling;1996] • Lack of career knowledge and progression • Longer working hours.

Other barriers that prevent women from entering Indian and Australian construction industry are as follows: 
TABLE I. BARRIERS PREVENTING WOMEN FROM ENTERING INTO INDIAN AND

\begin{tabular}{|l|l|}
\hline India & Australia \\
\hline Unequal pay & Gender stereotyping \\
\hline Caste and religion problem & Lack of awareness \\
\hline Poor sanitary facilities and health hazards & The rigidity of work roles \\
\hline Seasonal work irregularity & Flexibility issues \\
\hline Cultural restrictions & Changing family structure \\
\hline
\end{tabular}

Australian construction industry

Strategies to improve the participation of women in the industry: Measures or strategies are conceivable moves to encourage women's professional advancement in the development industry. Evaluating existing systems for supporting women in construction will help declare the research of proof-based procedures later. The proposals for enrolment of women into the development industry should begin from the schools, where they are taught about the prospects offered inside the industry. In addition, a powerful and dependable supportive network is important for womento survive in a male-dominated industry. Some of the measures to improve the involvement of womenare as follows: • Enhancing the image of the industry: Changing the negative image of the industry is important to enhance women's participation. Activities within the industry should welcome women tothe industry. Utilizing good examples to exhibit the profession potential and open doors for women could be used as a strategy. - Culture change: A fair working culture could be used as another strategy where men and women have their own rights and perspectives. - Building up a formal coaching or mentoring system would be helpful to improve the participation of women in the development trade. • Empowering women can be used as another strategy that helps them to have a proper balance in life. $\bullet$ Another proven system in the professional advancement of representatives is progressing dynamic andproductive training and career improvement.

\section{DISCUSSION}

There are many proven benefits for the participation of women in the industry. These include higher financial performance, improved modernization, decision making and improved customer relations. It is a fact that the participation of women in the construction industry is low when compared to men. This is due to the barriers or challenges prevailing in the industry [1 J. Watts;2007]. Hence, there is a need to overcome these barriers. • To maintain a proper work-life balance, allow flexible working hours based on domestic responsibilities. Develop 'career break' schemes that provide re-training for returning 
employees, promote work from home if it is possible and provide greater flexibility in working patterns. - Regarding sexual harassment, women workers should be given proper training and are essential to be aware of the problems related to harassment and bullying. Also, employers 27 must know about this undeniable and very normal problem prevailing in the industry and should be prepared to act immediately when terrible conduct is seen.

- Organising campaigns where youths can be instructed about the positive aspects of the industry. Welcoming good role models to schools and let them share their encounters and opportunities in the industry with the students. Arranging workshops for workshops on the best way to work effectively in a male-ruled the business with practical solutions. - Provide separate amenities for women, including toilets and changing room. Provide outfits designed for women. - Monitor attitudes and behaviour of co-workers to female professionals.

\section{CONCLUSION}

This paper evaluated the literature relating to the boundaries and challenges faced by women in the construction industry. Some of the difficulties faced by women in the industry are directly or indirectly related to gender. It is conceivable that the maleoverwhelmed, male-drove industry experiences an absence of gender diversity, making it troublesome for women for performing development jobs. It is found through the review analysis that image of the industry, culture and workplace, family responsibilities, maledominated culture and enrolment practices are the real hindrances to women in the development industry. When comparing two countries - Australia and India, it is understood that the role of women in the developed and developing country is strongly related to its culture. The similar barriers that could be seen in both countries are lower career progress, family issues, sexual harassment, male dominated the image of the industry, longer working hours, The negative image of the industry and lack of role models. Apart from these barriers, it is discovered that gender stereotyping, lack of awareness, the rigidity of work roles, flexibility issues and changing family structure are the main challenges faced by women in Australia. On the other hand, Unequal wages, caste and religion restrictions, poor sanitary facilities and seasonal workirregularity are those faced by women in India. The paper also provides some measures to improve theparticipation of women in the industry. This includes enhancement of the image of the industry, the introduction of proper networking and communication, proper training and mentoring, empowering women, and career development programs.

\section{FUTURE WORK AND RECOMMENDATIONS}

Considering this research work as a start, future research is expected to comprehend the hidden barriersfaced by women in the industries. Even though this research has 
identified the significant barriers confronting women's barriers across the world, a detailed investigation could be done to investigate the experience of women in the industry. Furthermore, future work can be extended to other countries as well. Comparing women's participation in the construction industry with other industries would also be helpful to understand the current level of participation. Future research should also upgrade the comprehension of the culture in the industry through an in-depth examination with respect to gender diversity.

\section{ACKNOWLEDGMENT}

First and foremost, I would like to express the deepest appreciation to my supervisor Professor Dr SilpiTewari, for her helpful guidance and support throughout the research as well as her valuable commentsto enhance the quality of content. I would like to express my sincere gratitude to my second supervisorDr Adam Krezel, who helped me to modify and improve my research. I would also like to extend my gratitude to Dr Dominic Doe Ahiaga-Dagbui who accepted and encouraged me with the research topic. Finally, I would like to thank my family and friends for their consistent support.

\section{REFERENCES}

A. Dainty and H. Lingard, "Indirect Discrimination in Construction Organizations and the Impact on Women's Careers", Journal of Management in Engineering, vol. 22, no. 3, pp. 108-118, 2006

"Balancing the BuildingTeam: Gender Issues in the Building Professions", 1995.

B. Baruah, "Women and globalisation: challenges and opportunities facing construction workers in contemporary India", Development in Practice, vol. 20, no. 1, pp. 31-44, 2010.

C. Menches and D. Abraham, "Women in Construction-Tapping the Untapped Resource to Meet Future Demands", Journal of Construction Engineering and Management, vol. 133, no. 9, pp. 701-707, 2007.

"Earnings and Earnings ratio", The Women's Bureau of the Department of Labour, 2021. [Online]. Available: https://www.dol.gov/agencies/wb.

"Economic empowerment of women: a comparative study of rural and urban women in Nagapattinam district, Tamil Nadu", journal of Xidian University, vol. 14, no. 12, 2020.

H. Lingard and J. Lin, "Career, family and work environment determinants of organizational commitment among women in the Australian construction industry", Construction Management and Economics, vol. 22, no. 4, pp. 409-420, 2004.

J. Rosa, C. Hon, B. Xia and F. Lamari, "Challenges, success factors and strategies for women's career development in the Australian construction industry", Construction Economics and Building, vol. 17, no. 3, pp. 27-46, 2017. 
J. Swanson, K. Daniels and D. Tokar, "Assessing Perceptions of Career-Related Barriers: The Career Barriers Inventory", Journal of Career Assessment, vol. 4, no. 2, pp. 219244, 1996.

J. Watts, "Porn, pride and pessimism: experiences of women working in professional construction roles", Work, Employment and Society, vol. 21, no. 2, pp. 299-316, 2007. Available: 10.1177/0950017007076641.

Linda Clarke, Elsebet Frydendal Pedersen, Elisabeth Michielsens, Barbara Susman,"The European Construction Social Partners: Gender Equality in Theory and Practice -, 2005", SAGE Journals, 2020.

M. Loosemore and T. Waters, "Gender Differences in Occupational Stress Among Professionals in the Construction Industry", Journal of Management in Engineering, vol. 20, no. 3, pp. 126-132, 2004.

N. Galea, A. Powell, M. Loosemore and L. Chappell, "Designing robust and revisable policies for gender equality: lessons from the Australian construction industry", Construction Management and Economics, vol. 33, no. 5-6, pp. 375-389, 2015.

R. Wentling, "A study of the career development and aspirations of women in middle management", Human Resource Development Quarterly, vol. 7, no. 3, pp. 253-270, 1996. Available: $10.1002 / \mathrm{hrdq} .3920070306$.

S. Banu and D. Kumar, "Working Conditions and Issues of Women Workers in an Unorganized Sector - Special Reference to Construction Sector of Thuraiyur Taluk,Tiruchirappalli", International Journal of Trend in Scientific Research and Development, vol. -2, no.-3, pp. 1369-1374, 2018

S. Fielden, M. Davidson, A. Gale and C. Davey, "Women in construction: the untapped resource", Construction Management and Economics, vol. 18, no. 1, pp. 113-121, 2000.

S. Sewalk and K. Nietfeld, "Barriers Preventing Women from Enrolling in Construction Management Programs", International Journal of Construction Education and Research, vol. 9, no. 4, pp. 239-255, 2013.

T. Toohey, D. Colosimo and A. Boak, "Australia's hidden resource: The economic case for increasing female participation,", JBWere, 2009. [Accessed 3 January 2021].

Received: $15^{\text {th }}$ February 2021; Accepted: 18 ${ }^{\text {th }}$ May 2021; First distributed: $18^{\text {th }}$ May 2021. 